\title{
The International Indigenous Policy Journal
}

Volume 6 | Issue 3

Article 3

June 2015

Biocultural Rights: A New Paradigm for Protecting Natural and Cultural Resources of Indigenous Communities

Cher Weixia Chen

George Mason University, wchen12@gmu.edu

Michael Gilmore

George Mason University, mgilmor1@gmu.edu

\section{Recommended Citation}

Chen, C. , Gilmore, M. (2015). Biocultural Rights: A New Paradigm for Protecting Natural and Cultural Resources of Indigenous Communities. The International Indigenous Policy Journal, 6(3).

DOI: 10.18584 /iipj.2015.6.3.3 


\title{
Biocultural Rights: A New Paradigm for Protecting Natural and Cultural Resources of Indigenous Communities
}

\begin{abstract}
This article proposes a new concept of "biocultural rights" that justly reflects a broader intellectual and policy trend to holistically address the protection of Indigenous natural and cultural resources. The concept of biocultural rights combines nature with culture; takes into consideration the past, the present, and the future; and values "special" Indigenous elements that are indispensable to the diversity of our universe. It aims at protecting Indigenous resources holistically and more effectively.
\end{abstract}

Keywords

Indigenous rights, biodiversity, cultural diversity

Acknowledgments

We would like to thank the editor and the reviewers for their time and valuable remarks.

\section{Creative Commons License} (c) $(1) \Theta(\Theta$

This work is licensed under a Creative Commons Attribution-Noncommercial-No Derivative Works 4.0 License. 


\section{Biocultural Rights: A New Paradigm for Protecting Natural and Cultural Resources of Indigenous Communities}

\section{Introduction: The Maijuna Community}

Throughout the world, the natural and cultural resources of Indigenous communities are under threat. The resources of the Maijuna Indigenous group of the northeastern Peruvian Amazon are no exception. The Maijuna, also known as the Orejón, are a Western Tucanoan people (Bellier, 1994; Steward, 1946). There are approximately 400 Maijuna individuals living in four communities: Sucusari along the Sucusari River, San Pablo de Totolla along the Algodón River, and Puerto Huamán and Nueva Vida along the Yanayacu River. These three river basins are part of the ancestral territory of the Maijuna (Gilmore, 2010).

The four Maijuna communities are recognized as Comunidades Nativas (Native Communities) by the Peruvian Government and each has been granted title to the land surrounding their community (BrackEgg, 1998). Unfortunately, the titled land that the Maijuna communities have received is a small portion of their ancestral territory. Therefore, hundreds of thousands of hectares of Maijuna ancestral land, the vast majority of which is intact primary rain forest, currently remains outside of direct Maijuna control and is unprotected. Notably, Maijuna ancestral territory is incredibly biologically rich and culturally important. For example, Maijuna traditional lands contain a complex of high terraces - an extremely unique and previously unknown habitat - that shelters a flora and fauna with new, rare, and specialized species. Additionally, this area also contains critically important hunting, fishing, and plant collecting sites as well as historical and sacred areas that help to sustain and nourish the Maijuna culture (Gilmore, 2010).

There are currently a wide variety of threats and challenges to Maijuna natural and cultural resources. For example, they are now under threat from loggers and poachers from outside communities. Even more serious, the Peruvian government is planning to build a $130 \mathrm{~km}$ long road, with a $5 \mathrm{~km}$ development corridor on either side of it focusing on biofuels production (e.g., oil palms), directly through the heart of Maijuna ancestral territory (Gilmore, 2010). The direct effects of highway construction and the associated impacts from an influx of colonists and subsequent deforestation would irreversibly alter the ecological fabric of this currently roadless area. Furthermore, given that the Maijuna are a forest dwelling people who rely on the forest for sustenance and survival, building this road would negatively impact their livelihood and traditional culture.

Regrettably, the Peruvian government has not properly consulted the Maijuna on the construction of the road nor has it accurately described both its biological and cultural ramifications (Gilmore, 2010). Perhaps not surprisingly, the Maijuna are adamantly against the construction of this road and its associated development corridor and are asking the Peruvian government to alter its path. They are also calling on the government to create a Regional Conservation Area that would formally and legally protect over 391,000 hectares of their ancestral lands and the critically important biological and cultural diversity found there. As stated, the Maijuna "strongly feel that their survival as a people and the survival and maintenance of their cultural practices, unique traditions, and traditional subsistence strategies depend on a healthy, intact, and protected ecosystem" (Gilmore, 2010, p. 233). In short, the Maijuna are fighting for their ancestral lands, natural and cultural resources, and the survival of their traditional 
culture, all of which are interlinked and interdependent, and they are looking for mechanisms to make this happen.

The vital role of natural and cultural resources ${ }^{1}$ to the well-being and survival of the Maijuna and other Indigenous communities has gained increasing notice among academics and international organizations (Tennant, 1994). ${ }^{2}$ Over the past several decades, various mechanisms have been proposed and employed to safeguard and protect both the natural and cultural resources of Indigenous peoples. The text below first evaluates these frameworks and offers critiques, followed by an analysis of the emerging recognition of the interconnections between Indigenous natural and cultural resources. This then leads to our proposed new concept_-"biocultural rights" — that attempts to solidify an approach to protecting Indigenous resources in a more holistic manner.

\section{Existing Frameworks Protecting Indigenous Resources}

The current system that is in place to protect Indigenous resources treats the land and other natural resources separately from cultural resources. There are two major mechanisms to protect natural resources of Indigenous groups: historical sovereignty and treaty rights. The concept of "historical sovereignty" was developed during the decolonization movement after World War II and then was adopted by the global Indigenous rights movement in the 1970s. In 2007, "historical sovereignty" became more than just a political claim, the United Nations (2007) Declaration on the Rights of Indigenous Peoples (hereinafter the 2007 U.N. Declaration) affirmed such concept as "the right to the lands, territories and resources which they have traditionally owned, occupied or otherwise used or acquired" (Article 26). However, it remains to be seen whether the soft law principle (as in the 2007 U.N. Declaration) of "historical sovereignty" could in the end become hard law or "permanent sovereignty" (Daes, 2005, p. 87).

The other mechanism is treaty rights (Goodin, 2000). A large number of treaties were created between Indigenous groups and their colonial governments during the 1700s and 1800s. However, the power imbalance between those two parties has resulted in significantly different interpretations of these treaties, which are largely detrimental to Indigenous peoples. Indigenous peoples have since lost much of their lands and natural resources. The 2007 U.N. Declaration in Article 37 has formally recognized

\footnotetext{
${ }^{1}$ Both natural resources and cultural resources are broadly defined. Natural resources are defined as those resources (actual and potential) that are derived or part of nature. They refer to an ecological system that includes biotic resources such as forests, animals, birds, fish, and abiotic resources such as land, water, ores, and air, as well as species and genes. Cultural resources are defined as cultural manifestations such as languages, oral traditions, philosophies, writing systems, archaeological and historical sites, artifacts, designs, ceremonies, sports and traditional games, and visual and performing arts and literature; spiritual and religious manifestations such as spiritual and religious traditions, customs and ceremonies, religious and cultural sites, ceremonial objects, and their human remains; and scientific and technological manifestations such as traditional medicines, human and genetic resources, seeds, traditional knowledge of the properties of fauna and flora, health practices, and sustenance practices such as hunting and fishing.

${ }^{2}$ There was little literature about Indigenous peoples in US legal journals until the year 1972 when the UN SubCommission on Discrimination and Protection of Minorities commissioned the Study on the Problem of Discrimination Against Indigenous Populations (United Nations Commission on Human Rights, 1986).
} 
the treaty rights of Indigenous peoples; yet, recent attempts to revive treaty rights by Indigenous peoples have not been very successful (Tsosie, 2000).

The protection of cultural and intellectual resources of Indigenous people was generally missing from the conversation prior to the 1980s. In 1984, the World Council of Indigenous Peoples (1984) declared that "Indigenous peoples will reassume original rights over material culture" in its Declaration of Principles (Article 14). In 1988, the First International Conference of Ethnobiology announced in its Declaration of Belem, "procedures should be developed to compensate native peoples for their knowledge" (cited in Hayden, 2003, p. 35). Later, the Kari-Oca Declaration addressed "culture, science and intellectual property" (World Conference of Indigenous Peoples, 1992, Introduction). And in 1993, the international legal arena witnessed its first document that is fully dedicated to the protection of cultural and intellectual property of Indigenous peoples: Mataatua Declaration on Cultural and Intellectual Property Rights of Indigenous Peoples (United Nations, 1993). Subsequently, Indigenous cultural and intellectual property emerged as an essential topic of international law, which is evinced by the rising number of regional declarations on Indigenous cultural and intellectual property. ${ }^{3}$ The international community came to an agreement as to the importance of Indigenous cultural and intellectual property during the deliberation of the $1994 \mathrm{draft}$ Declaration on the Rights of Indigenous Peoples (Gray, 1996). The World Intellectual Property Organization (WIPO) Intergovernmental Committee on Intellectual Property and Genetic Resources, Traditional Knowledge, and Folklore has been undertaking negotiations for a potential international legal instrument on the effective protection of Indigenous cultural resources. Indigenous communities have also been placed at the center stage of the international environmental movement, during which the debates have touched on various parts of the lives of Indigenous communities, such as cultural autonomy, traditional hunting and fishing practices, and traditional knowledge (Firestone, Lilley \& Noronha, 2005). For example, the importance of traditional ecological knowledge (TEK) has been widely acknowledged, as evidenced by the 2010 Nagoya Protocol, a supplementary agreement to the Convention on Biological Diversity that covers traditional knowledge associated with genetic resources (Bavikatte \& Robinson, 2011; McGregor, 2012).

The first mechanism commonly used to protect Indigenous peoples' cultural heritage utilizes the existing intellectual property (IP) laws. The commodification of intangible cultural and intellectual property such as music, motifs, prayers, ceremonies, and traditional knowledge as well as the alarming issue of "biopiracy"4 has been frustrating to many Indigenous communities (Daes, 1995; Robinson, 2010). The current legal frameworks have been inadequate in protecting Indigenous cultural and intellectual property (Paterson \& Karjala, 2003). The modes of classification, identification, and

\footnotetext{
${ }^{3}$ Such as, the Julayinbul Statement on Indigenous Intellectual Property Rights, Australia, November 1993; the Santa Cruz de la Sierra Statement on Intellectual Property, Bolivia, September 1994; the Tambunan Statement on the Protection and Conservation of Indigenous Knowledge, Malaysia, February 1995; the Suva Statement on Indigenous Peoples Knowledge and Intellectual Property Rights, Fiji, April 1995; and, the Kimberley Declaration, South Africa, August 2002.

4 "Biopiracy" was first defined by Pat Mooney and made well-known by other scholars such as Vandana Shiva. It refers to the "robbery of the biological raw materials" such as genetic resources and "the knowledge about the use of such resources". It is further defined as "the appropriation of the knowledge and genetic resources of farming and Indigenous communities by individuals or institutions who seek exclusive monopoly control (patents and intellectual property) over this knowledge and resources" (Martinez-Alier, 2003, p. 132).
} 
operation used under the current IP system of European origins (Deazley, 2004) are not compatible with Indigenous peoples' understanding of their knowledge and cultural practices (Bell \& Napolean, 2008). Furthermore, the present IP system that is mainly concerned with the protection of individual intellectual property does not take the interests of Indigenous communities into account, as Indigenous intellectual property is largely communal based and connects to Indigenous land and other natural resources (Davis, 1996/1997). Therefore, Indigenous peoples need to play a much bigger role in the decision-making process (Goldberg \& Badua, 2008). Some scholars have pushed to modify the current system to incorporate communal and collective ownership (Carpenter, 2004), to include more creative contractual provisions (Rubin \& Fish, 1994), to replace traditional intellectual property with "traditional resource rights" (Posey, Dutfield, Plenderleith, da Costa e Silva, \& Argumedo, 1996), and to have a "globally harmonized IP regime" (Sundaram, 2005, p. 577). Others have proposed abandoning all together the application of intellectual property rights (IPR) to the protection of cultural resources of Indigenous peoples (Heald, 2003).

The second mechanism employed by Indigenous peoples to protect their cultural resources is the claim of cultural rights. The most commonly accepted legally binding provision on cultural rights of Indigenous peoples is Article 27 of the International Covenant on Civil and Political Rights (ICCPR, 1967), which stipulates that minorities "shall not be denied the right to enjoy their own culture." However, this article has been a source of controversy since its inception. One issue is whether Article 27 only confers cultural rights as negative rights. That is, the wording of Article 27 holds a passive stance ("shall not be denied") with regard to such rights. Is a "passive" protection adequate to safeguard cultural rights? Nowak (1993) argued that currently the protection of cultural rights relies heavily on the active support of states because minority cultures are vulnerable to assimilation imposed by the majority group. Through its General Comment No. 23 issued in 2004 and various cases, the Human Rights Committee has implicitly interpreted cultural rights provided in Article 27 as a positive right (Kingsbury, 2001; Thornberry, 2001). Nevertheless, Article 27 has largely been interpreted as an individual right only; hence, it is limited in its ability to afford protection for Indigenous communal rights to their culture (Thornberry, 1991).

All of these mechanisms have both strengths and weaknesses in terms of protecting Indigenous natural and cultural resources. Each was developed out of its unique historical context and has its own theoretical support and institutional adherents. However, each can only solve one small fraction of the issue. Under these frameworks, the right of Indigenous peoples to their natural and cultural resources is viewed as two separate and independent issues; that is, the right to natural resources is separated from the right to cultural resources. The Maijuna case demonstrates that natural and cultural resources are inseparable, especially to Indigenous groups. As Elizabeth Burleson (2007) eloquently puts, "Chippewa cultural heritage is interwoven with the harvest of ancient wild rice. Pueblo ceremonial rights to clean water are equally central to retaining cultural heritage" (p. 252). Nature and culture are equally important to Indigenous peoples (Prosper, McMillan, Davis \& Moffitt, 2011). They are indivisible. Any damage to one will inevitably harm the other, threatening the very survival of Indigenous groups (Fonda, 2011; Robbins \& Dewar, 2011). Therefore a new concept—biocultural rights—ought to be established to unify all of these frameworks.

The historical development of international legal instruments on the rights of Indigenous peoples reveals a growing understanding of the intrinsic interdependence between the right to natural resources 
and the right to cultural resources. The following text examines the major international instruments on the rights of Indigenous peoples and argues that the mere fact that most of these documents address both natural resources and cultural resources (even though in separate articles) is indicative of the necessity of creating an inclusive right to protect both natural and cultural resources of Indigenous communities. The 2007 UN Declaration exhibits the very first step of this effort to holistically look at the protection of Indigenous peoples' resources as a whole.

\section{The International Legal Development on the Protection of Indigenous Resources}

\section{ILO Conventions 107 (1957) and 169 (1989)}

The Indigenous and Tribal Populations Convention of 1957 (ILO No. 107) was the first attempt under international law to codify nation states' obligations to Indigenous and tribal groups. National judiciary and international bodies have invoked it when dealing with issues such as Indigenous land rights (Morse \& Berger, 1992). However, its integrationist approach has been frequently criticized. Finally in 1989, Convention 169 replaced Convention 107 (Blaser, Feit \& McRae, 2004). Convention 169 changed the title from "population" to "peoples" and demonstrated a greater extent of respect for Indigenous groups as permanent entities rather than some temporary societies that would fade away under modernization. However, both conventions did not engage Indigenous peoples in their drafting process. Moreover, even though the newer Convention 169 did emphasize the importance of land and other natural resources to Indigenous people in Part II, it did not specifically address the issue of the protection of their cultural and intellectual property, which reflected the dominant discourse on the protection of Indigenous rights of the time.

\section{UN Conference on Environment and Development (UNCED): Agenda 21}

Agenda 21 (United Nations, 1992) is an action plan that came out of the 1992 UN Rio Conference on Environment and Development. In this conference, Indigenous peoples were actively involved and fought to be a part of the agenda and conversation. Chapter 26 of Agenda 21 explicitly aimed to strengthen the role of Indigenous people and their communities in sustainable development. It recognized the importance of Indigenous lands and other natural resources as well as their traditional knowledge, and intellectual and cultural property.

More specifically, Chapter 26 emphasizes "the interrelationship between the natural environment and its sustainable development and the cultural, social, economic and physical well-being of Indigenous people" (United Nations, 1992, sec. 26.1). This is a major development in the international Indigenous movement, as the "interrelationship" between nature and culture for the first time was formally recognized in an important international document.

\section{Convention on Biological Diversity (1993)}

Another important international legal document that developed out of the Rio Conference is the Convention on Biological Diversity (United Nations Environment Programme, 1993). It recognized the importance of traditional knowledge and methods conducive to biodiversity conservation. It urged their generalization, dissemination, and compensation, and obliged contracting parties to provide reasonable access to genetic resources in their sovereign territories on the basis of prior informed consent (PIC) 
and equitable sharing of benefits (UN, 1993, Article 8 \& Article 15). The convention also stresses the importance of protecting and encouraging the use of "biological resources in accordance with traditional cultural practices that are compatible with conservation or sustainable use requirements" (UN, 1993, Article 10).

\section{UN Declaration on the Rights of Indigenous Peoples (2007)}

This 2007 UN Declaration represented a dynamic and significant development in the Indigenous rights movement and sets a new international standard on the treatment of Indigenous peoples. It recognized the rights of Indigenous people to natural resources as well as their right to cultural resources. In Article 8 , it establishes the interdependence between Indigenous land and other natural resources and their cultural survival. Specifically, Article 8.1 stated, "Indigenous peoples and individuals have the right not to be subjected to forced assimilation or destruction of their culture" (UN, 2007). And in the ensuing Article 8.2 it stipulated that "states shall provide effective mechanisms for prevention of, and redress for: any action which has the aim or effect of dispossessing them of their lands, territories or resources..." (UN, 2007). That is, the dispossession of Indigenous lands, territories, or resources may lead to "destruction of their culture." In this way, the Declaration formally stresses the integrative value of Indigenous lands and other natural resources to the endurance of Indigenous cultures (Article 8). And, in Article 25, the Declaration further elaborates on the intricate spiritual relationship between Indigenous peoples and their natural resources (UN, 2007).

\section{Declaration of Indigenous Peoples of Africa on Sustainable Development and Rio +20} (2012)

In 2012, Indigenous groups of Africa emerged in the international environmental movement and issued their own declaration on sustainable development (United Nations, 2012). They appealed to the international community to be included in sustainable development and called for the recognition of the contributions Indigenous peoples could make in finding sustainable solutions by employing their "traditional knowledge." The Declaration also stressed the significance of Indigenous knowledge to sustainable development policy formulation (Article 13). It specifically emphasized that their right to access and manage Indigenous lands and territories is key to promoting the "conservation of ecosystems" (Article 12). Later, the Indigenous Peoples International Declaration on SelfDetermination and Sustainable Development (Rio $+20,2012)$ further underscored the fundamental role of Indigenous cultures to sustainable development.

\section{Other Recent Developments}

All of these international documents have played an essential role in setting norms and providing justifications that have served and will continue to serve as a shared reference to and source of validation for better treatment of Indigenous peoples. From no reference to Indigenous cultural resources in early documents to the highlighted interrelationship between nature and culture in more recent ones, they have collectively indicated an emerging tendency within the international community towards a more holistic and inclusive approach to Indigenous rights. 
More international organizations are calling for such an approach. For instance, the UN Permanent Forum on Indigenous Peoples has repeatedly stressed the crucial inclusion of Indigenous peoples in biodiversity discussions.

Biodiversity erosion is a serious concern for us - Indigenous peoples - because the loss of flora, fauna, and micro- organisms and the destruction of ecosystems are not just physical losses. This also means the loss of Indigenous knowledge systems, cultures, languages, and our identities. (Tauli-Corpuz, 2009, p. 6)

Indigenous peoples have long recognized the ingrained interdependence of biodiversity and cultural diversity, both of which are considered by Indigenous communities as invaluable (Matsui, 2012; Sarma \& Barpujari, 2011).

Other international organizations such as the United Nations Development Program (UNDP) have also advocated for more research on the intimate relationship and connection between cultural diversity and biodiversity and more collaboration between organizations committed to promoting and conserving either cultural diversity or biodiversity (Fourmile, 1996). The United Nations Educational, Scientific and Cultural Organization (UNESCO) and the International Union for the Conservation of Nature (IUCN) have made similar policy initiatives. There also has been the emergence of "biocultural community protocols" developed by NGOs such as Natural Justice and the Compass Network, and national policy initiatives such as the Indigenous People's Rights Act of the Philippines (Section 35) that acknowledge the interrelationship between biodiversity and cultural diversity (Maffi, 2010).

By the same token, several relatively recent legal cases also suggest that some supranational adjudicatory bodies have been willing to embrace a more inclusive approach to Indigenous rights. The InterAmerican Court on Human Rights in the case Community Mayagna (Sumo) Awas Tingni v Nicaragua (2001) ruled against the government-approved logging operations that violated the Mayagna Indian Community's land rights. The Court acknowledged the culturally and environmentally destructive nature of commercial logging and upheld the customary rights of the Indigenous community to their ancestral lands and traditional way of life such as hunting. It held that "for Indigenous communities, relations to the land are not merely a matter of possession and production but a material and spiritual element which they must fully enjoy, even to preserve their cultural legacy and transmit it to future generations" (Community Mayagna (Sumo) Awas Tingni v Nicaragua, 2001). The Court also pointed out in Yakye Axa v. Paraguay (2005) that "it is necessary to take into account that the land is closely linked to their oral expressions and traditions, their customs and languages, their arts and rituals, their knowledge and practices in connection with nature, culinary art, customary law, dress, philosophy, and values" (Yakye Axa v. Paraguay, 2005, para. 154).

Similarly, the Inter-American Commission on Human Rights in another well-publicized case, Comunidad Yanomami (1985), held that the construction of a highway by Brazil through the ancestral lands of the Yanomami had threatened the survival of the Indigenous community and violated their right to life, liberty and personal security. In particular, the Commission considered "all the negative consequences for their culture, traditions and customs resulting from displacing the Indians from their ancestral lands" (Comunidad Yanomami, 1985). That is, the Commission acknowledged the detrimental effects of losing their lands on Yanomami culture. 
The Human Rights Committee has also acknowledged the importance of land to the culture of Indigenous peoples (Anaya, 1996). In the case of Lubicon Lake Band v. Canada (1990), the Committee found that the devastating environmental impact, which resulted from oil and gas extraction on Indigenous lands, constituted a violation of Indigenous right to culture under Article 27 of ICCPR. Even the dissenting opinion by Mr. Nisuke Ando conceded that "it is not impossible that a certain culture is closely linked to a particular way of life and that industrial exploration of natural resources may affect the Band's traditional way of life, including hunting and fishing" (Lubicon Lake Band v. Canada, 1990, Appendix I).

These cases, in conjunction with the emergence of norm-setting international documents, signify a developing international commitment to the rights of Indigenous peoples to both their natural and cultural resources. They indicate an increasing respect for Indigenous communities that is long overdue. One way to further this movement in Indigenous rights is to develop a more holistic approach to protecting natural and cultural resources of Indigenous peoples. Here this article advocates a new concept: "biocultural rights."

\section{Biocultural Rights}

As indicated above, international law is moving towards a broader and more holistic approach in regards to Indigenous rights. However, it seriously lacks a discussion of the exact content of this approach (Gillespie, 2000). As a response, the concept of biocultural rights attempts to address the content of such a holistic approach. The current approach to protecting Indigenous resources treats the right to natural resources and the right to cultural resources separately and neglects the important interconnectedness between the two. In contrast, here we define biocultural rights (see Figure 1) as a set of substantive Indigenous resource rights that simultaneously protect both Indigenous natural and cultural resources, realizing that they are inextricably linked and interconnected.

The concept of biocultural rights emphasizes the interdependent and interlinked nature of Indigenous resources; that is, the existence of Indigenous cultural resources is dependent on Indigenous natural resources and vice versa. As a legal concept, biocultural rights would integrate the current fragmented and separate systems of substantive Indigenous rights to natural and cultural resources. There has been ample literature calling for caution to proceed with the creation of new rights (Heald \& Sherry, 2000). However, biocultural rights are not additional new rights for Indigenous groups; instead, they are rights that unify the existing resource rights of Indigenous peoples.

In terms of interpretation, the concept of biocultural rights should be broad enough to allow interpretation variation. A homogenizing model imposed on all nation states with widely different biological, cultural, political and economic contexts can only lead to resistance. The interpretation ought to take greater consideration of Indigenous peoples and effectively engage Indigenous communities. Certainly a pro-Indigenous perspective is necessary considering the struggles Indigenous peoples are facing (Gray, 2009). 


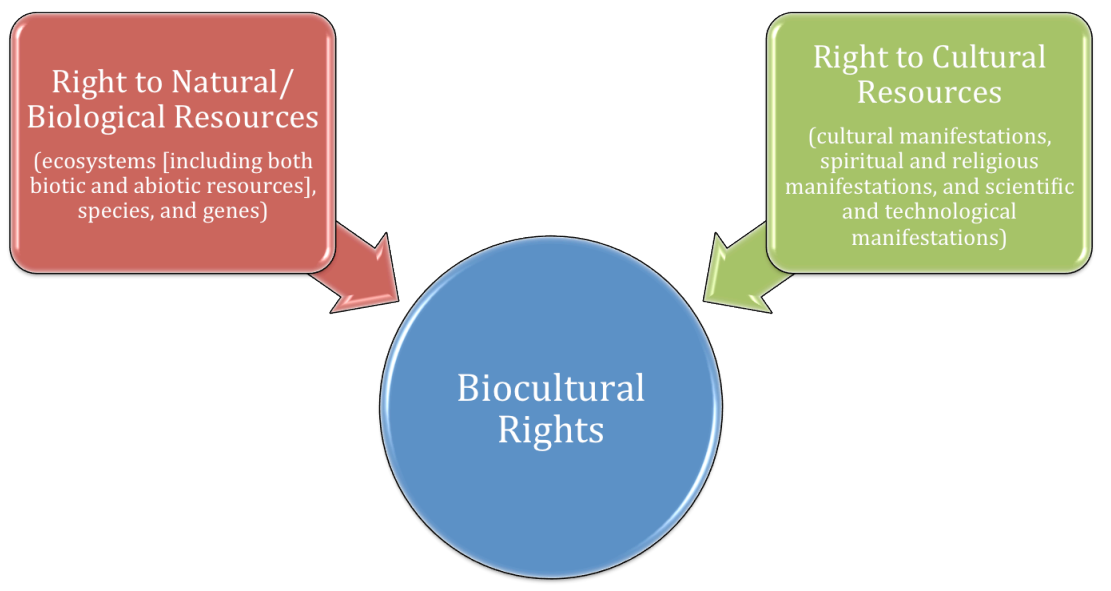

Figure 1. Conceptualization of biocultural rights.

The ultimate philosophical foundation for the concept of biocultural rights lies in its "holistic" feature. This holistic feature is embodied in three aspects. First, the concept combines nature with culture. Biodiversity and cultural diversity are interdependent and inextricably linked. Second, the concept connects the past, the present and the future. It is a concept that takes into consideration of the past, the present and the future in the sense that it is premised on the distinctive histories and wrongs that Indigenous groups have experienced, the examination of the present system, and the very need to help and empower these groups to conserve their distinct biocultural diversity for future generations. Third, this concept considers the "special" element of Indigenous communities and the "universal" interest.

The concept of biocultural rights assumes that Indigenous peoples ought to have the right to maintain their distinct biocultural heritage, which is essential to the maintenance of biodiversity and cultural diversity worldwide. It is the concern to conserve, respect, and protect special Indigenous elements (both biological and cultural) that are indispensable to the diversity of our universe that is behind biocultural rights. In this sense, it is both special and universal.

The idea of biocultural rights is more than a legal notion. It is a new paradigm. Lack of a common Indigenous agenda has been listed as one of the key obstacles to the successful protection of Indigenous rights (Preston, Vinding, \& Garcia-Alix, 2007). Therefore, this concept could provide a fresh overall guiding principle to further solidify and strengthen the Indigenous rights movement. At the UN level, the norm of biocultural rights, if accepted and diffused, could help legitimize the holistic protection of Indigenous resources as a shared commitment among its operational agencies, with the ultimate goal of being codified in a legally binding international document. When it comes to national policy-making and academic discourse on Indigenous issues, this concept could offer a new perspective on how to approach the protection of Indigenous resources holistically. 
The concept of biocultural rights justly reflects a broader intellectual and policy trend to holistically address the protection of Indigenous natural and cultural resources and to realize "freedom and equality through rights accorded to human individuals or collectivities” (Kingsbury, 2001, pp. 239-240). This right is much needed and is justified by several reasons outlined below.

First, practically speaking, many Indigenous communities throughout the world have been forcibly removed from their lands for a wide variety of ill-conceived reasons, including in the aftermath of tourism expansion (Oei A \& Shepherd, 2010). The not-so-rare instances of ethnocide further suggest that Indigenous peoples are struggling everyday to maintain their very existence. The Zapatista in Mexico and the Yanomami in Brazil are indicative of the horrifying effects of ethnocide (Maybury-Lewis, 2002). Raphael Lemkin first coined the term "ethnocide" as an alternative to genocide. He referred to it as the physical, biological, and cultural dimensions of genocide (Jacobs, 2002). Therefore, to combat ethnocide that encompasses physical, biological, and cultural elements, we will have to use an approach that addresses all these elements simultaneously. The concept of biocultural rights justly provides such an approach.

Second, as mentioned above, international governing bodies and non-governmental organizations as well as national governments have started to integrate biodiversity and cultural diversity debates. The various international documents and the growing body of legal practice are beginning to establish some common understandings on the necessary convergence of both debates. The concept of biocultural rights is hence crucial in order to take advantage of this convergence to ensure policy coherence.

Third, it is important to note that the legal convergence and integration of debates on the protection of biodiversity and cultural diversity have been at least partially driven and strengthened by the existence and continued development of a relatively new field (since the early 1990s) of academic inquiry, research, and action that centers on the notion of biocultural diversity. As defined by Maffi (2010), a leader in this burgeoning field, "biocultural diversity comprises the diversity of life in all of its manifestations - biological, cultural, and linguistic — which are interrelated (and likely co-evolved) within a complex socio-ecological adaptive system" (p. 5). Importantly, the inextricable link that exists between biological (which in this essay is largely interchangeable with natural), cultural, and linguistic diversity is recognized not only by studying global, regional, and national level correlations but also via causal relationships between cultures and biodiversity on a local level (Maffi, 2010). In short, this lends further credence to the push to more holistically address the protection of Indigenous natural and cultural resources via the concept of biocultural rights.

And, fourth, the absence of a single unifying concept in the existing international legal framework has created enormous challenges for both Indigenous peoples and states (Kingsbury, 2001). The concept of biocultural rights will be of fundamental importance in addressing Indigenous issues that commonly intersect with complicated histories, cultures, and politics. Biocultural rights will provide a linkage between the relevant mechanisms on protecting Indigenous resources that have been fragmented in the human rights, intellectual property, and environmental legal frameworks (Bavikatte \& Robinson, 2011).

Then, what would biocultural rights mean for the Maijuna? To bring us back to our opening discussion concerning the Maijuna, biocultural rights could be used and harnessed in a variety of ways. First, if codified as a legal tool, biocultural rights would provide them with a much stronger and more holistic 
legal framework to fight against the construction of the proposed road and development corridor that is threatening their ancestral lands, biological resources, and cultural traditions. Instead of having to fight for their natural and cultural resources through disjunct and separate legal mechanisms, which would be problematic and challenging, biocultural rights would unify their legal challenge under one framework. Second, from a policy perspective, in order to better and more holistically protect the rights and resources of the Maijuna, biocultural rights could provide a guiding principle or framework for the Peruvian Government to follow as they design a policy regarding the Maijuna. Third, from the perspective of the Indigenous rights movement, biocultural rights could become the goal for nongovernmental organizations (NGOs) and activists working with the Maijuna, as it would help to focus and unite their efforts. And, fourth, biocultural rights would provide a new paradigm for academic discourse and research on the Maijuna. In short, biocultural rights would help to recognize and push what the Maijuna have known and stated all along: Their long-term health, vitality, and survival as a people are not only dependent on the recognition of their rights to cultural resources but also their rights to biological resources as well. That is, without a stable, intact, and protected ecosystem and homeland, their survival as a people and the survival of their language, cultural traditions, and traditional subsistence strategies would be in danger. In the end, biological and cultural diversity is interconnected and interdependent, which should not only be legally recognized but also operationalized on the ground as well.

\section{Conclusion}

Biocultural rights are not only justifiable, but also necessary. It is justifiable as they can help to begin to right past injustices that have been carried out against Indigenous peoples, which have served to deny them of their rights to land, territory, means of livelihood, language, cultural identity, and ways of life, among others. However, the appeal is also to the future. Indigenous peoples have special characteristics and their very existence adds tremendously to the biocultural diversity of our world (Guruswamy, Roberts, \& Drywater, 1999). To have a holistic framework that helps protect their rights, we will have to pay close attention to the protection of their natural and cultural resources, both of which are inextricably linked to each other and both of which are essential to the survival of Indigenous peoples. That is, biocultural rights are to help right past wrongs that have been perpetuated on Indigenous peoples and to protect their communities for future generations.

There are multiple dimensions of policy implications with biocultural rights. For the UN and its operational agencies, it is time to use a new paradigm of biocultural rights to integrate the existing programs on Indigenous rights and strive towards a more holistic legal document that codifies this claim. The NGOs and activists working on Indigenous rights may utilize biocultural rights as a shared commitment to harmonize their efforts to better protect Indigenous communities. As for national policy-makers, biocultural rights could guide them in designing a more inclusive policy with regard to Indigenous peoples.

To have a distinct framework that is dedicated to the protection of Indigenous peoples has been one of the aspirations of the international Indigenous movement (Kingsbury, 2001). With the advent of an umbrella right - biocultural rights - a new and exciting energy could move us forward to a better and more just future for Indigenous peoples and for humankind. As the UN (2007) Declaration justly states, 
"all peoples contribute to the diversity and richness of civilizations and cultures, which constitute the common heritage of humankind" (Preamble). 


\section{References}

Anaya, S. J. (1996). Indigenous peoples in international law. Oxford: Oxford University Press.

Bavikatte, K., \& Robinson, D. F. (2011). Towards a people's history of the law: Biocultural jurisprudence and the Nagoya Protocol on access and benefit sharing. Law, Environment and Development Journal, 7(1), 35-51. Retrieved from http://www.leadjournal.org/content/11035.pdf

Bell, C. E. \& Napolean, V. (Eds., 2008). First Nations cultural heritage and law: Case studies, voices, and perspectives. Vancouver: University of British Columbia Press.

Bellier, I. (1994). Los Maihuna. In F. Santos \& F. Barclay (Eds.), Guía etnográfica de la Alta Amazonía (pp. 1-180). FLACSO-SEDE.

Blaser, M., Feit, H. A. \& McRae, G. (2004). Indigenous peoples and development processes: New terrains of struggle. In M. Blaser, H. A. Feit \& G. McRae (Eds.), In the way of development (pp. 1-25). New York: Zed Books.

Brack-Egg, A. (1998). Amazonia: Biodiversidad, comunidades, y desarrollo (CD-ROM). DESYCOM (GEF, PNUD, UNOPS, Proyectos RLA/92/G31, 32, 33, and FIDA). Lima, Peru.

Burleson, E. (2007). Tribal, state, and federal cooperation to achieve good governance. Akron Law Review, 40(2), 207-254.

Carpenter, M. (2004). Intellectual property law and indigenous peoples: Adapting copyright law to the needs of a global community. Yale Human Rights and Development Law Journal, 7, 52-78.

Comunidad Yanomami. (1985). Caso No 7615. Resolución No 12/85. [ENG]. Retrieved from http://www.cidh.org/annualrep/84.85eng/Brazil7615.htm

Community Mayagna (Sumo) Awas Tingni v Nicaragua (Merits, Reparations and Costs), 31 Aug. 2001, Ser. C, No. 79.

Daes, E. I. (1995). Final report on the protection of the heritage of Indigenous peoples. Retrieved from http://www.ifeanet.org/multimedia/comite/doc/UN-Daes-1995-en.pdf

Daes, E. I. (2005) Indigenous peoples' rights to land and natural resources. In N. Ghanea \& A. Xanthaki (Eds.), Minorities, peoples and self-determination (pp. 75-92). Danvers, MA: Martinus Nijhoff Publishers.

Davis, M. (1996/1997). Indigenous peoples and intellectual property rights (Research Paper No. 20). Canberra: Australian Parliamentary Library.

Deazley, R. (2004). On the origin of the right to copy: Charting the movement of copyright law in eighteenth-century Britain (1695-1775). Oxford: Hart Publishing. 
Firestone, J., Lilley, J. \& Noronha, I. T. de. (2005). Cultural diversity, human rights, and the emergence of Indigenous peoples in international and comparative environmental law. American University International Law Review, 20(2), 219-292.

Fonda, M. (2011). Introductory essay: Traditional knowledge, spirituality and lands. The International Indigenous Policy Journal, 2(4), 1. Retrieved from http://ir.lib.uwo.ca/iipj/vol2/iss4/1

Fourmile, H. (1996). Making things work: Aboriginal and Torres Strait Islander involvement in bioregional planning: Approaches to bioregional planning. Part 2. Background papers to the conference, 30 October - 1 November 1995. Melbourne: Department of the Environment, Sport and Territories.

Gillespie, A. (2000). International environmental law, policy and ethics. Oxford: Oxford University Press.

Gilmore, M. P. (2010). The Maijuna: Past, present, and future. In M. Gilmore et al. (Eds.), Perú: Maijuna. Rapid biological and social inventories report 22 (pp. 226-232). Chicago: The Field Museum.

Goldberg, D. M. \& Badua, B. (2008). Do people have standing? Indigenous peoples, global warming, and human right. Barry Law Review, 11(1), 59-76.

Goodin, R. E. (2000). Waitangi tales. Australasian Journal of Philosophy, 78(3), 309-333.

Gray, A. (1996). Indigenous rights and development: Self-determination in an Amazonian community. Oxford: BerghahnBook.

Gray, A. (2009). Indigenous peoples and their territories. In A. D. Oliveira (Ed.), Decolonising Indigenous rights (pp.17-44). Nova York: Routledge.

Guruswamy, L., Roberts, J. C., \& Drywater, C. (1999). Protecting the cultural and natural heritage: Finding common ground. Tulsa Law Journal, 34(4), 713-744.

Hayden, C. (2003). When nature goes public: The making and unmaking of bioprospecting in Mexico. Princeton: Princeton University Press.

Heald, P. J. (2003). The rhetoric of biopiracy. Cardozo Journal of International and Comparative Law, 11, 519-546.

Heald, P. J., \& Sherry, S. (2000). Implied limits on the legislative power: The intellectual property clause as an absolute constraint on Congress. University of Illinois Law Review, 2000(4), 1119-1197.

International Covenant on Civil and Political Rights (ICCPR). GA res. 2200A (XXI), 21 UN GAOR Supp. (No. 16) at 52, UN Doc. A/6316 (1966); 999 UNTS 171; 6 ILM 368 (1967). 
International Labour Organization (ILO). (1957). Convention Concerning the Protection and Integration of Indigenous and Other Tribal and Semi-Tribal Populations in Independent Countries (ILO No. 107). 328 UNTS 247.

International Labour Organization (ILO). (1989). Convention Concerning Indigenous and Tribal Peoples in Independent Countries (ILO No. 169). 72 ILO Official Bull. 59; 28 ILM 1382.

Jacobs, S. L. (2002). Genesis of the concept of genocide according to its author from original sources. Human Rights Review, 3(2), 98-103.

Kingsbury, B. (2001). Reconciling five competing conceptual structures of Indigenous peoples' claims in international and comparative law. International Law and Politics, 34(1), 189-250.

Lubicon Lake Band v. Canada. Communication No. 167/1984 (26 March 1990), U.N. Doc. Supp. No. $40(\mathrm{~A} / 45 / 40)$ at $1(1990)$.

Maffi, L. (2010). What is biocultural diversity? In L. Maffi \& E. Woodley (Eds.), Biocultural diversity conservation: A global sourcebook (pp. 3-11). London: Earthscan.

Martinez-Alier, J. (2003). The environmentalism of the poor: A study of ecological conflicts and valuation. Northhampton: Edward Elgar Publishers.

Matsui, K. (2012). Water ethics for First Nations and biodiversity in Western Canada. The International Indigenous Policy Journal, 3(3), 4. Retrieved from http://ir.lib.uwo.ca/iipj/vol3/iss3/4

Maybury-Lewis, D. (2002). Indigenous peoples, ethnic groups, and the state (2nd ed.). Boston and London: Allyn and Bacon.

McGregor, D. (2012). Traditional knowledge: Considerations for protecting water in Ontario. The International Indigenous Policy Journal, 3(3), 11. Retrieved from http://ir.lib.uwo.ca/iipj/vol3/iss3/11

Morse, B., \& Berger, T. (1992). Sardar Sarovar: Report of the independent review. Ottawa: Resource Futures International.

Nowak, M. (1993). UN Covenant on Civil and Political Rights: CCPR commentary. Strasbourg: N.P. Engel.

Oei A, K. S., \& Shepherd, J. (2010). In land we trust: The Endorois' communication and the quest for Indigenous peoples' rights in Africa. Buffalo Human Rights Law Review, 16, 43-57.

Paterson, R. K., \& Karjala, D. S. (2003). Looking beyond intellectual property in resolving protection of the intangible cultural heritage of Indigenous peoples. Cardozo Journal of International and Comparative Law, 11, 633-670. 
Posey, D. A., Dutfield, G., Plenderleith, K., da Costa e Silva, E., \& Argumedo, A. (1996). Traditional resource rights: International instruments for protection and compensation for Indigenous peoples and local communities. Gland: International Union for the Conservation of Nature.

Preston, J., Vinding, D. \& Garcia-Alix, L. (2007). Indigenous rights: The UN Special Rapporteur experiences and challenges. Copenhagen: IWGIA.

Prosper, K., McMillan, L. J., Davis, A. A., \& Moffitt, M. (2011). Returning to Netukulimk: Mi'kmaq cultural and spiritual connections with resource stewardship and self-governance. The International Indigenous Policy Journal, 2(4), 7. Retrieved from http://ir.lib.uwo.ca/iipj/vol2/iss4/7

Rio +20: Indigenous Peoples International Declaration on Self-Determination and Sustainable Development. (2012, June 21). Retrieved from http:// www.iwgia.com

Robbins, J. A., \& Dewar, J. (2011). Traditional indigenous approaches to healing and the modern welfare of traditional knowledge, spirituality and lands: A critical reflection on practices and policies taken from the Canadian Indigenous example. The International Indigenous Policy Journal, 2(4), 2. Retrieved from http://ir.lib.uwo.ca/iipj/vol2/iss4/2

Robinson, D. F. (2010). Confronting biopiracy: Challenges, cases and international debates. London/Washington, DC: Earthscan.

Rubin, S., \& Fish, S. (1994). Biodiversity prospecting: Using innovative contractual provisions to foster ethnobotanical knowledge, technology, and conservation. Colorado Journal of International Law and Policy, 5, 23-58.

Sarma, U. K., \& Barpujari, I. (2011). Eco-cosmologies and biodiversity conservation: Continuity and change among the Karbis of Assam. The International Indigenous Policy Journal, 2(4), 10. Retrieved from http://ir.lib.uwo.ca/iipj/vol2/iss4/10

Steward, J. H. (1946). Western Tucanoan tribes. In J. H. Steward (Ed.), Handbook of South American Indians (vol. 3; pp. 737-748). Washington, DC: Smithsonian Institution.

Sundaram, S. (2005). Battling bills, beans and biopiracy. Albany Law Journal of Science and Technology, $15(2), 545-578$.

Tauli-Corpuz, V. (2009). The importance of Indigenous peoples in biodiversity conservation. Retrieved from http://siteresources.worldbank.org/EXTENVMAT/Resources/30113501271279658247/VP1-TauliCorpuz.pdf

Tennant, C. (1994). Indigenous peoples, international institutions, and the international legal literature from 1945-1993. Human Rights Quarterly, 16(1), 6-24.

Thornberry, P. (1991). International law and the rights of minorities. Oxford: Clarendon Press. 
Thornberry, P. (2001). An unfinished story of minority rights. In A. M. Biro \& P. Kovacs (Eds.), Diversity in action. Local public management of multiethnic communities in Central and Eastern Europe (pp. 45-74). Budapest: LGI.

Tsosie, R. (2000). Sacred obligations: Intercultural justice and the discourse of treaty rights. UCLA Law Review, 47, 1615-1672.

United Nations. (1992). Agenda 21. Proc. of United Nations Conference on Environment \& Development, Brazil, Rio De Janerio. UN, 1992. Retrieved from http://www.un.org/esa/sustdev/documents/agenda21/english/Agenda21.pdf

United Nations. (1993). The Mataatua Declaration on Cultural and Intellectual Property Rights of Indigenous Peoples. New York: Commission on Human Rights, Subcommission on Prevention of Discrimination and Protection of Minorities, Working Group on Indigenous Populations. GE 93-14346.

United Nations. (2007). United Nations Declaration on the Rights of Indigenous Peoples, G.A. Res. 61/295, U.N. Doc. A/RES/61/295 (Sept. 13, 2007), 46 I.L.M. 1013.

United Nations. (2012). Declaration of indigenous peoples of Africa on sustainable development and Rio+20. Retrieved from http: / / www.uncsd2012.org/index.php?page=view\&nr=1151\&type=230\&menu=38

United Nations Commission on Human Rights. (1986). Study of the problem of discrimination against Indigenous populations (E/CN.4/RES/1986/35). Retrieved from http://www.refworld.org/docid/3b00f02630.html

United Nations Environment Programme. (1993). Convention on Biological Diversity. ATS 32 / 1760 UNTS 79 / 31 ILM 818 (1992).

World Conference of Indigenous Peoples on Territory, Environment and Development. (1992). KariOca Declaration. Kari-Oca, Brazil.

World Council of Indigenous Peoples. (1984). World Council of Indigenous Peoples Declaration of Principles. The Center for World Indigenous Studies. Retrieved from http://cwis.org

Yakye Axa v Paraguay (Merits, Reparations and Costs), 17 June 2005, Ser. C, No. 125. 